\title{
Analisis Hubungan Ekspor, Pembayaran Hutang Luar Negeri Dan Nilai Tukar Terhadap Cadangan Devisa Indonesia
}

\author{
Fakhrurrazi $^{* a}$,Hijri Juliansyah ${ }^{* b}$ \\ *Fakultas Ekonomi dan Bisnis Universitas Malikussaleh \\ a Corresponding author: hijri.juliansyah@gmail.com \\ b cascfachrurrazi@gmail.com
}

\section{A R T I C L E I N F O R M A T I O NA B S T R A C T}

Keywords:

Exports, Foreign Debt

Payment, Exchange Rates,

Foreign Exchange

Reserves, ARDL.
This study aims to determine the relationship between exports, foreign debt payments, and the exchange rates on the foreign exchange reserves of Indonesia in 1988-2019. This study uses secondary data for 31 years and uses the Autoregressive Distributed Lag (ARDL) analysis method to analyze the data. The results of this study indicate that all variables have no relationship between variables, only on the foreign exchange reserves to exports. In short-term testing, the export does not have a significant effect on foreign exchange reserves, and the foreign debt payment and the exchange rate have a significant effect on foreign exchange reserves. However, in the long run, all variables do not have a significant effect on foreign exchange reserves.

\section{PENDAHULUAN}

Dalam satu dekade terakhir ini negara Indonesia terus mengalami perubahan pada cadangan devisanya. Cadangan devisa Indonesia terus mengalami peningkatan, data Badan Pusat Statistik (BPS) menunjukkan dari tahun 2008 hanya sebesar US\$ 51,639 juta namun pada tahun 2019 meningkat drastis menjadi US\$ 129.183 juta. Beberapa indikator penyokong meningkatnya cadangan devisa tersebut adalah penerimaan devisa migas, ekspor, hutang luar negeri dan penanaman modal (investasi portofolio) dalam (Mildyanti.T 2019) .

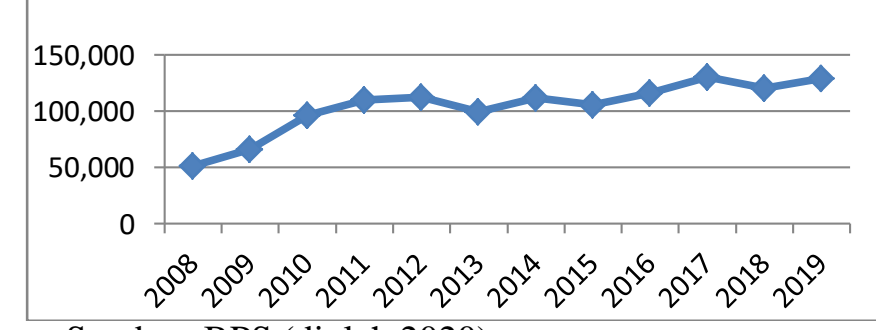

Sumber :BPS (diolah 2020)

\section{Gambar 1.1 Grafik perkembangan cadangan devisa Indonesia tahun 2008 - 2019 \\ Dari Gambar 1.1. grafik perkembangan} cadangan devisa Indonesia tahun 2008 - 2019 diatas dapat dilihat perkembangan cadangan devisa meningkat drastis dari tahun 2008 hingga tahun 2019 .dimana hanya terjadi sedikit penurun di tahun 2013 karena adanya peningkatan pembayaran hutang luar negeri menyebabkan menurunnya cadangan devisa Indonesia. luar negeri yang dianggap sebagai mesin penggerak pertumbuhan ekonomi oleh berbagai negara di dunia (Traore 2019)

Berbagai literatur menjelaskan salah satu indikator yang mempengaruhi cadangan devisa adalah ekspor. Ekspor merupakan faktor terpenting dalam perdagangan internasional, karena dengan adanya ekspor suatu negara dapat memperluas pasar baik dari segi kualitas barang maupun dari sektor ekonomi lainya ekspor berpengaruh positif dan signifikan terhadap cadangan devisa. artinya dengan meningkatnya ekspor maka akan meningkatkan juga cadangan devisa (Devi Andriyani, 2019).

Berikut disajikan data perkembangan cadangan devisa Indonesia, ekspor, pembayaran hutan luar negeri dan nilai tukar dari tahun 2013 2019.

Tabel 1.1

Data Cadangan Devisa, Ekspor, Pembayaran Hutang Luar Negeri dan Nilai Tukar Tahun $2015-2019$ 


\begin{tabular}{|l|l|l|l|l|}
\hline 2015 & $150,366.20$ & $14,105.69$ & 13,795 & 105,931 \\
\hline 2016 & $145,186.20$ & $15,007.88$ & 13,600 & 116,362 \\
\hline 2017 & $168,828.10$ & $16,590.69$ & 13,548 & 130,196 \\
\hline 2018 & $180,012.70$ & $19,519.91$ & 14,710 & 120,654 \\
\hline 2019 & $167,525.00$ & $21,400.00$ & 13,901 & 129.183 \\
\hline
\end{tabular}

Sumber: BPS(diolah 2020)

Berdasarkan data pada tabel.1.1 data cadangan devisa, ekspor, pembayaran hutang luar negeri dan nilai tukar tahun 2015 - 2019. pada tahun 2017 ke tahun 2018 terjadi fenomena, dimana ekspor tahun 2017 sebesar US\$ 168,828,10 meningkat pada tahun 2018 menjadi US\$ 180,012.70 sedangkan cadangan devisa terjadi penurunan dari US\$130,196 juta ditahun 2017 turun menjadi US\$120,654 juta pada tahun 2018. Pada tahun 2018 ke tahun 2019 juga terjadi fenomena dimana ekspor menurun dari US\$ 180,012.70 menjadi US\$ 167,525.00. Jika dilihat pada data tersebut ekspor tidak mempengaruhi cadangan devisa Seharusnya jika ekspor meningkat maka cadangan devisa juga akan meningkat. Karena ekspor dapat mempengaruhi cadangan devisa (Benny 2013).

Selain ekspor, indikator lain yang mempengaruhi cadangan devisa suatu negara adalah pembayaran hutang luar negeri. Indonesia merupakan salah satu negara berkembang dimana perlu banyak melakukan pembangunan di segala bidang untuk meningkatkan kesejahteraan masyarakat. Salah satu sumber pendanaan penting yang digunakan Indonesia untuk melaksanakan pembangunan adalah peningkatan devisa melalui penambahan hutang luar negeri.

Dalam jangka panjang jika pembangunan infrastruktur tersebut tidak tepat sasaran tentu akan menguras cadangan devisa karena tingginya beban hutang yang harus dilunasi setiap tahunnya. Oleh sebab itu pemerintah perlu berhati-hati dan harus melakukan pembayaran hutang luar negeri untuk mengurangi beban hutang Pembayaran hutang luar negeri memiliki hubungan yang sangat erat dengan cadangan devisa. Karena devisa merupakan sumber pembayaran hutang luar negeri (Ridho, 2015)

Berdasarkan data BPS pada tabel 1.1 data cadangan devisa, ekspor, pembayaran hutang luar negeri dan nilai tukar tahun 2013 - 2019. Terjadi beberapa fenomena pada data variabel pembayaran hutang luar negeri dan cadangan devisa. Dimana pada tahun 2015 ke tahun 2016 pembayaran hutang luar negeri meningkat dari sebelumnya sebesar Rp14,106 Miliyar meningkat ke Rp 15,007,88 Miliyar namun cadangan devisa juga mengalami peningkatan dari US\$105,931 juta menjadi US\$ 116,362 juta, seharusnya jika pembayaran hutang luar negeri meningkat maka cadangan devisa akan menurun karena pembayaran hutang luar negeri menggunakan cadangan devisa. Teori ini didukung oleh hasil penelitian yang dilakukan (Asrianti, 2018) yang menyimpulkan bahwa pembayaran hutang luar negeri berpengaruh negatif terhadap cadangan devisa indonesia, artinya jika terjadi kenaikan pembayaran utang luar negeri maka akan menyebabkan penurunan cadangan devisa.

Indikator lain yang dapat mempengaruhi cadangan devisa suatu negara adalah nilai tukar. Nilai tukar rupiah adalah salah satu faktor dalam menentukan jumlah cadangan devisa yang dimiliki.

Kemudian pada tabel 1.1 data cadangan devisa, ekspor, pembayaran hutang luar negeri dan nilai tukar tahun 2013 - 2019. Pada variabel nilai tukar Mencatat pergerakan nilai tukar dalam beberapa tahun terakhir, terhitung ditahun 2013 ke 2014 nilai tukar rupiah melemah dari USD $1 \$=$ Rp 12.189,00 menjadi USD 1\$ = Rp 12.440,00 akan tetapi berbeda dengan cadangan devisa yang justru menguat dari US\$ 92,872 juta ke US\$ 105,504 juta. Seharusnya jika nilai tukar rupiah melemah maka cadangan devisa menurun sebagai mana pada hasil penelitian yang dilakukan oleh Ridho yang menyimpulkan bahwa nilai tukar Berpengaruh Signifikan Terhadap Cadangan Devisa artinya memiliki hubungan yang searah, jika terjadi pelemahan nilai tukar rupiah maka cadangan devisa akan mengalami penurunan, begitu juga sebaliknya penguatan nilai tukar rupiah maka cadangan devisa akan meningkat (Ridho, 2015)

Penelitian sebelumnya telah banyak mengkaji tentang variabel ekspor dan nilai tukar terhadap cadangan devisa. Seperti penelitian yang dilakukan (Benny 2011), (Sayoga, 2017), (Kuswantoro, 2017) dan (Ridho, 2015) akan tetapi dalam penelitian tersebut tidak adanya variabel pembayaran hutang luar negeri. Sementara (Asrianti, 2018) juga telah meneliti cadangan 
devisa Indonesia tetapi tidak melibatkan variabel nilai tukar.

Penemuan penelitian diatas telah memberi fokuskan pada cadangan devisa. Tidak seperti kajian di atas, dimana metode analisis dengan menggunakan regresi linear berganda. Penelitian ini meliputi ekspor, pembayaran hutang luar negeri dan nilai tukar sebagai faktor yang mempengaruhi cadangan devisa dengan menggunakan inovasi dalam metode analisis dengan menggunakan model ARDL yang dianggap dapat memberikan informasi mengenai tingkah laku jangka pendek suatu variabel terhadap jangka panjangnya akibat adanya perubahan yang permanen pada periode 19882019 guna untuk memperkaya pengetahuan empiris yang ada pada cadangan devisa.

Penelitian ini bertujuan untuk mengetahui dan menganalisis hubungan ekspor, pembayaran hutang luar negeri dan nilai tukar terhadap cadangan devisa Indonesia.

Selanjutnya bagian kedua dari penelitian ini akan membahas tinjauan teoritis, metode penelitian akan dibahas pada bagian ketiga. Kemudian pada bagian ke empat akan dibahas hasil penelitian dan pembahasan. Pada bagian kelima akan membahas kesimpulan dan saran.

\section{LANDASAN TEORITIS}

\section{Cadangan Devisa}

Cadangan devisa bisa didefinisikan sebagai semua aktiva luar negeri yang dikuasai oleh otoritas moneter yang bisa digunakan setiap saat untuk membiayai ketidakseimbangan neraca pembayaran dalam berbagai tranksaksi internasional atau dalam stabilitas moneter dengan melakukan campur tangan di pasar valuta asing dan untuk berbagai tujuan lainnya. Dari definisi tersebut manfaat cadangan devisa yang dimiliki suatu negara dapat dipergunakan untuk menjaga stabilitas nilai tukar dan untuk membiayai defisit pada neraca pembayaran (Benny, 2013).

Menurut Hamdy dalam buku Iskandar Putong (2013) cadangan devisa adalah mata uang asing atau alat pembayaran lainnya yang di gunakan untuk membiayai tranksaksi ekonomi keuangan internasional dan yang mempunyai catatan kurs resmi pada bank central

Cadangan devisa suatu negara dipengaruhi oleh transaksi berjalan dan ekspor. Bertambah atau berkurangnya cadangan devisa akan terlihat dari neraca lalu lintas moneter. Besar kecilnya akumulasi cadangan devisa suatu negara biasanya ditentukan oleh kegiatan perdagangan (ekspor dan impor) dengan arus modal negara tersebut. Dan kecukupan cadangan devisa ditentukan oleh besarnya kebutuhan impor dan sistem nilai tukar yang digunakan (Pridayanti, 2014).

\section{Ekspor}

Ekspor merupakan proses transportasi barang atau komoditas dari suatu negara ke negara lain melalui kesepakatan dalam proses perdagangan internasional. Menurut sukirno dalam (Benny, 2013) Ekspor adalah pembelian negara luar atas barang produksi perusahaan-perusahaan di dalam negeri. Faktor terpenting yang menentukan ekspor adalah kemampuan dari Negara tersebut untuk mengeluarkan barang barang yang dapat bersaing dalam pasaran luar negeri. Ekspor akan secara langsung mempengaruhi pendapatan nasional dan pertambahan cadangan devisa. Akan tetapi, hubungan yang sebaliknya tidak selalu berlaku, yaitu kenaikan pendapatan nasional atau cadangan devisa belum tentu menaikkan ekspor oleh karena pendapatan nasional dapat mengalami kenaikan sebagai akibat dari kenaikan pengeluaran rumah tangga, investasi perusahaan, pengeluaran pemerintah dan penggantian barang impor dengan barang buatan dalam negeri. Dan juga penarikan hutang dari luar negeri juga menjadi sebab naiknya pendapatan nasional.(Devi Andriyani, 2019)

Menurut Amir M. S dalam penelitian (Marulitua, 2017) pengertian ekspor adalah perdagangan dengan mengeluarkan barang dari dalam ke luar pabean Indonesia dengan memenuhi ketentuan-ketentuan berlaku.

\section{Pembayaran Hutang Luar Negeri}

Dalam kamus besar bahasa Indonesia (KBBI) Pembayaran adalah proses memberikan uang atau benda untuk pengganti barang atau hutang yang telah di terima.sedangkan hutang luar negeri adalah sebagian dari total hutang suatu 
negara yang diperoleh dari para kreditor di luar negara tersebut. Penerima hutang luar negeri dapat berupa pemerintah, perusahaan atau perorangan. Bentuk hutang dapat berupa uang yang diperoleh dari bank swasta, pemerintah negara lain atau lembaga keuangan internasional seperti IMF dan Bank Dunia (Ulfa, 2017).

Pembayaran hutang luar negeri juga didefinisikan sebagai proses yang memberikan sesuatu untuk pengganti kembali atas suatu pinjaman yang telah diterima, suatu pinjaman yang bersumber dari luar negeri untuk memenuhi kebutuhan modal dalam negeri yang di perlukan untuk pembangunan. Dan berkewajiban harus membayar kembali dalam waktu dan tempo tertentu.

Menurut Teori Ricardian bahwa kebijakan utang luar negeri untuk membiayai defisit anggaran belanja pemerintah tidak akan mempengaruhi pertumbuhan ekonomi. Hal ini terjadi karena efek pertumbuhan pengeluaran pemerintah yang dibiayai dengan utang harus dibayar oleh pemerintah pada masa yang akan datang dengan kenaikan pajak (Astanti, 2015).

Utang luar negeri dapat diartikan berdasarkan berbagai aspek. Menurut Triboto, berdasarkan aspek materiil, pinjaman luar negeri merupakan arus masuk modal dari luar negeri ke dalam negeri yang dapat digunakan sebagai penambahan modal di dalam negeri. Berdasarkan aspek formal, pinjaman luar negeri merupakan penerimaan atau pemberian yang dapat digunakan untuk meningkatkan investasi guna menunjang pertumbuhan ekonomi. Sedangkan berdasarkan aspek fungsinya, pinjaman luar negeri merupakan salah satu alternatif sumber pembiayaan yang diperlukan dalam pembangunan.

\section{Nilai Tukar}

Nilai tukar atau biasa disebut dengan kurs adalah jumlah uang domestik yang dibutuhkan yaitu banyaknya rupiah yang dibutuhkan untuk memperoleh satu unit mata uang asing. Nilai tukar merupakan salah satu variabel yang penting dalam suatu perekonomian terbuka, sebab variabel tersebut berpengaruh pada variabel lain antara lain harga, tingkat bunga, neraca pembayaran, serta transaksi berjalan (Pridayanti, 2014).

Kesimpulannya bahwa Nilai Tukar adalah sebuah Perjanjian yang menjadi tolak ukur nilai tukar mata uang terhadap pembayaran tranksaksi sekarang atau nanti di kemudian hari antara dua mata uang dalam masing masing negara atau lebih.

Menurut samuelson dalam Iin Nurul Yuliyanti (2014) Nilai tukar valuta asing adalah harga satu satuan mata uang dalam satuan mata uang lain. Nilai tukar valuta asing ditentukan dalam pasar valuta asing, yaitu pasar tempat berbagai mata uang yang berbeda diperdagangkan.

\subsection{Kerangka Konseptual}

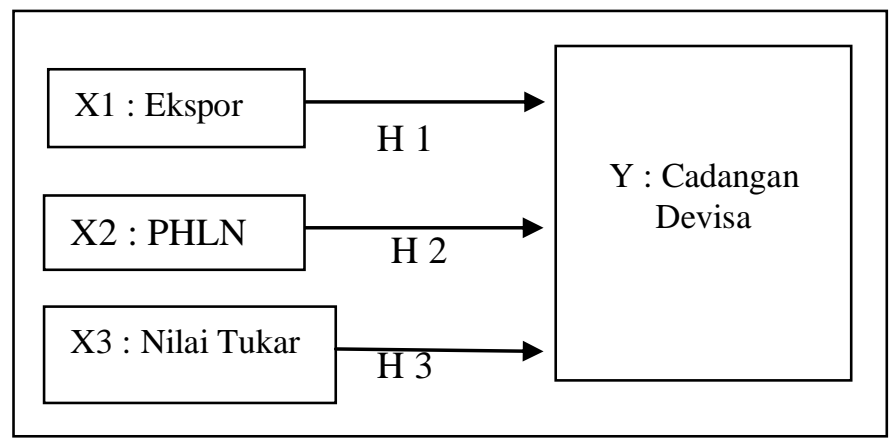

\section{Gambar 2.1 kerangka Konseptual Penelitian}

Penelitian ini menggunakan dua variabel penelitian yaitu Variabel Dependen, yaitu variabel yang dipengaruhi atau tertanggung oleh variabel lain. Variabel dependen yang digunakan dalam penelitian ini adalah Cadangan Devisa (Y). Variabel Independen, yaitu variabel yang bebas dan tidak terpengaruh oleh variabel lain. Variabel independen yaitu ekspor (X1), pembayaran hutang luar negeri (X2), dan nilai tukar (X3).

\section{Hipotesis Penelitian}

Adapun hipotesis Alternatif dalam penelitian ini adalah sebagai berikut :

H1 : Diduga variabel ekspor, memiliki hubungan yang signifikan terhadap cadangan devisa Indonesia.

H2 : Diduga variabel Pembayaran hutang luar negeri memiliki hubungan yang signifikan terhadap cadangan devisa Indonesia. 
H3 : Diduga variabel nilai tukar tidak memiliki hubungan yang signifikan Indonesia. terhadap cadangan devisa

\section{METODE PENELITIAN}

Data dan Sumber Data

Penelitian ini menggunakan data sekunder, yang dimaksud dengan data sekunder adalah data yang telah diolah oleh pihak lain. Data yang digunakan tahun 1988-2019. Data utama di dalam penulisan proposal ini bersumber dari Badan Pusat Statistik dan Kementrian Keuangan.

\section{Definisi Operasionalisasi Variabel}

Operasionalisasi variabel merupakan petunjuk bagaimana variabel-variabeldalam penelitian diukur. Untuk memperjelas dan mempermudah pemahaman terhadap variabel-variabel yang akan dianalisis dalam penelitian ini, maka butuh dirumuskan operasionalisasi variabel yaitu sebagai berikut:

a) Cadangan Devisa : yaitu simpanan valuta asing indonesia dengan satuan nilai mata uang juta USD (\$).

b) Ekspor adalah proses perpindahan barang dari satu negara kenegara lain melalui perturan dan ketentuan resmi yang sudah di tetapkan dengan satuan juta USD (\$).

c) Pembayaran Hutang Luar Negeri adalah sejumlah uang yang harus dibayarkan atau dikeluarkan oleh pemerintah untuk melunasi sejumlah hutang di luar negeri. Dengan satuan hitung Miliyar rupiah (Rp).

d) Nilai Tukar sebuah perjanjian pembayaran saat kini atau di kemudian hari, antara dua mata uang masing-masing negara atau wilayah.Dalam penelitian ini nilai tukar menggunakan satuan hitung Rupiah ( Rp).

\section{Metode Analisis Data}

Untuk menganalisis pengaruh Ekspor ,Pembayaran Hutang Luar Negeri dan Nilai Tukar Terhadap Cadangan Devisa di Indonesia data dianalisis dengan menggunakan model alat analisis ARDL (Autoregressive Distributed Lag). penentuan alat analisis ini dilakukan setelah menguji stasioner data. Uji stasioner dapat dilakukan dengan cara tahap pengujian terhadap ada tidaknya unit root dalam variabel dengan uji Philips_perront (PP), adanya unit root akan menghasilkan persamaan atau model regresi lancung ternyata data tersebut stasioner di fist different. Secara garis besar, langkah-langkah yang akan dilakukan untuk analisis ekonometri dengan menggunakan metode ini adalah sebagai berikut:

1) Menguji stasioneritas data variabel variabel dalam model penelitian, baik pada tingkat level maupun tingkat first difference.

2) Penentuan lag optimum

3) Uji kausalitas granger

4) Uji kointegrasi bound test.

5) Mengestimasi model ARDL

6) Uji Stabilitas Model ARDL

\section{Uji Stasioneritas}

Uji stasionaritas data dalam penelitian menggunakan model dinamis sangat penting dilakukan, alasannya untuk menghindri adanya regresi lancing (spurious regression) dalam mengestimasi sebuah model (Puspita, 2017). Uji stasioneritas ini juga sering disebut dengan uji unit root test. Terdapat beberapa cara dalam melakukan pengujian unit root test. Diantaranya adalah Augmented Dikey Fuller dan Philips-Perron.

Keduanya menidentifikasi keberadaan unit root sebagai hiptesis null. Dalam penelitian ini uji unit root test akan dilakukan dengan metode Philips-Perron (PP) . pengujian dengan metode Philips-Perron (PP) merupakan pengembangan pada Dickey Fuller (DF) dengan memperbolehkan asumsi adanya distribusi error. Dalama uji DF digunakan asmsi adanya error yang homogen dan independen. Sedangkan PP dapat mengakomodasikan adanya error yang dependen dan terdistribusi secara heterogen(Mufidah A. 2011).

\section{Penentuan Lag Optimum}

Tahap kedua di dalam analisis ARDL adalah penentuan lag optimum. Penentuan jumlah lag dalam model ARDL ditentukan pada kriteria informasi yang direkomendasikan oleh nilai terkecil dari Final Prediction Error (FPE), Akaike Information Criterion (AIC), Schwarz Criterion (SC), dan Hannan-Quinn (HQ). Program Eviews telah memberi petunjuk tanda bintang bagi lag yang ditetapkan sebagai lag optimum.

Dalam sebuah penelitian dinamis penetuan lag optimum berguna untuk menunjukkan berapa lama reaksi suatu variabel terhadap variabel lainnya. Disamping itu penentuan lag optimum berguna untuk menghilangkan masalah autokorelasi dalam sebuah system. 
Dalam penelitian ini penentuan lag optimum menggunakan kriteria AIC minimum yaitu Akaike Information Creterion (AIC) :

$$
-2(1 / \mathrm{T})+2(\mathrm{k}-\mathrm{T}) \text {. }
$$

\section{Uji Kausalitas Granger}

Metode yang digunakan untuk menganalisis hubungan kausalitas antar variabel yang diamati adalah dengan uji kausalitas Granger. Dalam penelitian ini hubungan kausalitas yang dilihat adalah hubungan kausalitas antara cadangan devisa dengan ekspor dan sebaliknya, cadangan devisa dengan pembayaran hutang luar negeri dan sebaliknya, cadangan devisa dengan nilai tukar dan sebaliknya. Secara umum suatu persamaan granger dapat diinterpretasikan sebagai berikut:

1. Uninderectional causalitydari variabel dependen ke variabel independen. Hal ini terjadi ketika koefisien lag variabel dependen secara statistik signifikan berbeda dengan nol, sedangkan koefesien lag seluruh variabel independen sama dengan nol.

2. Feedback/bilateral causalityjika koefisien lag seluruh variabel, baik variabel dependen maupun variabel independen secara statistik signifikan berbeda dengan nol.

3. Independence jika koefisien lag seuruh variabel, baik variabel dependen maupun independen secara statistik tidak berbeda dengan nol.

Setelah dilakukannya uji kointegrasi johansen, dimana hasilnya menunjukkan variabel terkointegrasi. Adanya kointegrasi keduanya berarti ada hubungan atau keseimbangan jangka panjang antara variabel. Dalam jangka pendek mungkin saja ada ketidak keseimbangan (disequilibrium). Persamaan ARDL Engle Granger adalah sebagai berikut :

$$
\Delta \mathrm{Yt}=\alpha 0+\alpha 1 \Delta \mathrm{Xt}+\alpha 2 \mathrm{ECt}+\mathrm{et}
$$

Dimana :

$$
\begin{aligned}
& \mathrm{Y}=\text { Variabel yang diamati } \\
& \mathrm{ECt}=(\mathrm{Yt}-1-\beta 0-\beta 1 \mathrm{Xt}-1) \\
& \mathrm{T}=\text { Trend waktu }
\end{aligned}
$$

Dalam hal ini koefisien $\alpha 1$ adalah koefisien jangka pendek sedangkan $\beta 1$ adalah koefisien jangka panjang. Koefisien koreksi ketidak keseimbangan $\alpha 2$ dalam bentuk nilai absolut menjelaskan seberapa cepat waktu diperlukan untukmendapatkan nilai keseimbangan.
Pengambilan keputusan dalam uji kausalitas dapat dilakukan dengan membandingkan nilai tstatistikestimasi dengan nilai t-tabelatau dengan melihat nilai probabilitas F-statistik. Jika nilai tstatistikhasil estimasi lebih besar dari nilai ttabelatau nilai probabitas F-statistik $<\dot{\alpha}=5 \%$, maka $\mathrm{H} 0$ di tolak artinya terdapat pengaruh antara dua variabel yang diuji, dan begitu juga sebaliknya.

\section{Uji Kointegrasi Bound Test}

Uji kointegrasi dilakukan untuk menguji apakah variabel-variabel yang tidak stasioner pada data level terkointegrasi antara satu variabel dengan variabel yang lain. Kointegrasi ini terbentuk apabila kombinasi antara variabel- variabel yang tidak stasioner menghasilkan variabel yang stasioner. Apabila terdapat persamaan sebagai berikut:

$$
\mathrm{yt}=\beta 0+\beta 1 \mathrm{x} 1+\mathrm{et}
$$

Maka, error dari persamaan tersebut dapat ditulis menjadi:

$$
\text { et }=y \mathrm{t}-\beta 0-\beta 1 \mathrm{x} 1
$$

dengan catatan bahwa et merupakan kombinasi linear dari $\mathrm{x} 1$ dan $\mathrm{x} 2$. Konsep kointegrasi yang diperkenalkan oleh Engle dan Granger pada tahun 1987 mensyaratkan bahwa et haruslah stasioner pada I(0) untuk dapat menghasilkan keseimbangan jangka panjang. Pada penelitian ini uji kointegrasi dilakukan dengan menggunakan metode Bound Testing Cointegration dengan pendekatan ARDL yang diperkenalkan oleh Pesara dan Shin (2001) dalam (Fadhilah Nu, 2017). Metode tersebut dilakukan dengan cara membandingkan nilai Fstatistik hitung dengan nilai krisis upper bound $(\mathrm{I}(0))$.

\section{Model ARDL (Autoregressive Distributed Lag)}

Model ARDL (Autoregressive Distributed Lag) adalah pengaruh variabel $\mathrm{X}$ dan $\mathrm{Y}$ dari waktu ke waktu termasuk pengaruh variabel $\mathrm{Y}$ dari masa lampau terhadap nilai Y masa sekarang (Fadhilah $\mathrm{Nu}, 2017)$. penelitian ini menggunakan spesifikasi model Autoregressive Distributed Lag (ARDL). Adapun model umum dari ARDL adalah sebagai berikut :

$$
\Delta Y t=\beta_{O}+\sum_{i=1}^{n} \beta_{1} \Delta Y_{t-i}+\sum_{i=0}^{n} \delta_{1} \Delta X_{t-i}+\varphi_{1} y_{t-1}+\varphi_{2}{ }_{t-1}+\mu_{t} \text { ? }
$$

\section{Dimana:}

$\beta_{t}, \delta_{t}:$ Koefisien jangka pendek 


\section{$\beta_{t}, \delta_{t}:$ Koefisien ARDL jangka panjang $\mu_{t}:$ Disturbance error (white noise)}

Sebagaimana telah disebutkan bahwa keunggulan ARDL adalah kemampuannya untuk mendeteksi dinamika jangka panjang maupun jangka pendek. Dalam model umum ARDL pada persamaan (1) merupakan persamaan untuk hubungan jangka pendek(Zaretta 2019).

$$
\sum_{i=1}^{n} \beta_{1} \Delta Y{ }_{t-i}+\sum_{i=0}^{n} \delta_{1} \Delta X_{t-i}
$$

Adapun untuk hubungan jangka panjang ditunjukkan oleh

$$
\varphi_{1} y_{t-1}+\varphi_{2} x_{t-1}+\mu_{t}
$$

Metode estimasi yang akan digunakan adalah menggunakan pendekatan Autoregressive Distributed Lag (ARDL). Model ARDL dipilih oleh karena dengan menggunakan ARDL akan mampu melihat pengaruh $\mathrm{Y}$ dan $\mathrm{X}$ dari waktu ke waktu, berikut juga pengaruh variabel $\mathrm{Y}$ masa lampau terhadap Y masa kini.

\section{Uji Stabilitas Model ARDL}

Uji stabilitas model ARDL dalam penelitian ini menggunakan uji CUSUM dengan tingkat kepercayaan 95\%. Hasil uji CUSUM untuk model ARDL dalam penelitian ini Stabililitas model ditentukan dari posisi CUSUM line yang berwarna biru berada diantara dua significance line 5\% yang berwarna merah. Untuk model ARDL CUSUM line berada diantara significance line yang membuktikan bahwa model ARDL stabil

\section{PEMBAHASAN}

\section{Uji stasioneritas}

Uji stasioneritas sering disebut juga uji unit root test. Kemudian untuk melihat data stasioner atau tidak kita dapat mengujinya pada beberapa level, jika data tidak stasioner pada level 1(0) maka uji stasioner dapat diturunkan menjadi first Different 1(1),kemudian jika pada first different data masih tidak stasioner maka uji stasioner dilakukan pada Seccond Different 1(2) (Masta, 2014). Syarat untuk berlakunya Var adalah apabila data stasioner pada ordo yang sama.namun setelah dilakukan pengujian data ternyata data ini stationer di first different.oleh karena itu penelitian ini berfokus menggunakan alat analisis model ARDL Hasil Uji Unit Root Test Philips Perront (PP) dapat kita lihat pada tabel berikut ini:

\begin{tabular}{|c|c|c|c|c|}
\hline Variabel & Unit Root & $\begin{array}{l}\text { Phillips- } \\
\text { Perron test } \\
\text { statistic } \\
\end{array}$ & $\begin{array}{c}\text { Critical } \\
\text { Value 5\% }\end{array}$ & Prob PP \\
\hline \multirow{3}{*}{ Caadev } & Level & -1.980939 & -3.562882 & 0.5885 \\
\hline & First Diff & -5.404649 & -3.568379 & 0.0007 \\
\hline & Second Diff & -25.18428 & -3.574244 & 0.0000 \\
\hline \multirow{3}{*}{ Ekspor } & Level & -2.046744 & -3.562882 & 0.5538 \\
\hline & First Diff & -4.654497 & -3.568379 & 0.0043 \\
\hline & Second Diff & -10.69235 & -3.574244 & 0.0000 \\
\hline \multirow{3}{*}{ PHLN } & Level & -1.910457 & -3.562882 & 0.6251 \\
\hline & First Diff & -5.246081 & -3.568379 & 0.0010 \\
\hline & Second Diff & -12.41253 & -3.574244 & 0.0000 \\
\hline \multirow{3}{*}{$\begin{array}{l}\text { Nilai } \\
\text { Tukar }\end{array}$} & Level & -2.316547 & -3.562882 & 0.4133 \\
\hline & First Diff & -5.362767 & -3.568379 & 0.0008 \\
\hline & Second Diff & -10.68769 & -3.574244 & 0.0000 \\
\hline
\end{tabular}

Tabel 4.1 Uji Unit Root Test Philips - Perront

Sumber: eviews10 Data Diolah,2020

Dari tabel 4.1 Uji Unit Root Test PhilipsPerront dapat disimpulkan bahwa semua variabel dalam penelitian ini stasioner pada first different variabel cadangan devisa, ekspor, pembayaran hutang luar negeri dan nilai tukar memiliki tingkat stasionertas yang sama yaitu pada first deffernt dan second defferent dengan menggunakan regresi konstan (Intercep) pada level 1\%, 5\%, dan $10 \%$. Dimana nilai probabilitasnya lebih kecil dari 0,05 ( Prob < 0,05). Ini bermakna bahwa semua variabel dapat diteruskan pengujian baik menggunakan first different maupun second different. Untuk penelitian ini menggunakan first different.

\section{Penentuan lag optimum}

Penentuan jumlah lag dalam model ARDL ditentukan pada kriteria informasi yang direkomendasikan oleh nilai terkecil dari Final Prediction Error (FPE), Akaike Information Criterion (AIC), Schwarz Criterion (SC), dan Hannan-Quinn (HQ). Program Eviews telah memberi petunjuk tanda bintang bagi lag yang 
ditetapkan sebagai lag optimum. Dalam sebuah penelitian dinamis penetuan lag optimum berguna untuk menunjukkan berapa lama reaksi suatu variabel terhadap variabel lainnya.

\section{Tabel Hasil Uji Lag Optimum}

\begin{tabular}{|ccccccc|}
\hline \hline Lag & LogL & LR & FPE & AIC & SC & HQ \\
\hline \hline 0 & -1277.503 & NA & $1.49 e+32$ & 85.43355 & 85.62038 & 85.49332 \\
1 & -1169.663 & 179.7335 & $3.31 e+29$ & 79.31088 & $8024501^{*}$ & 79.60971 \\
2 & -1143.305 & $36.90151^{*}$ & $1.77 e+29^{*}$ & $78.62033^{*}$ & 8030177 & $79.15823^{*}$ \\
\hline \hline
\end{tabular}

Sumber: eviews10 Data Diolah ,2020

Berdasarkan tabel 4.2 hasil penentuan lag optimum dalam penelitian terdapat pada lag kedua . Dimana pada lag ini terhimpun nilai terendah dari LR (sequential modified LR test statistic (each test at 5\% level), FPE (Final prediction error), nilai AIC (Akaike information criterion), dan nilai HQ (Hannan-Quinn information criterion) terletak pada Lag 2, sedangkan SC. Namun jika diakumulasikan maka jumlah bintang terbanyak terdapat pada Lag 2 yang kemudian dapat disimpulkan bahwa Lag Optimum berada pada Lag 2 (Marwanti 2017).

\section{Uji Kausalitas Granger}

Dalam penelitian ini hubungan kausalitas yang dilihat adalah hubungan kausalitas antara cadangan devisa dengan ekspor dan sebaliknya, cadangan devisa dengan pembayaran hutang luar negeri dan sebaliknya, cadangan devisa dengan nilai tukar dan sebaliknya. Berikut disajikan data hasil pengujian kausalitas:

\section{Tabel 4.3 Hasil Uji Kausalitas Granger}

\begin{tabular}{|lccc|}
\hline Null Hypothesis: & Obs & F-Statistic & Prob. \\
\hline \hline EKSPOR does not Granger Cause CADEV & \multirow{2}{*}{30} & 1.02529 & 0.3733 \\
CADEV does not Granger Cause EKSPOR & & 8.99232 & 0.0011 \\
\hline \hline PHLN does not Granger Cause CADEV & \multirow{2}{*}{30} & 0.57609 & 0.5694 \\
CADEV does not Granger Cause PHLN & & 0.31367 & 0.7336 \\
\hline \hline NILAI_TUKAR does not Granger Cause CADEV & \multirow{2}{*}{30} & 1.17790 & 0.3244 \\
CADEV does not Granger Cause NILAI_TUKAR & & 1.65767 & 0.2109 \\
\hline \hline PHLN does not Granger Cause EKSPOR & \multirow{2}{*}{30} & 1.25499 & 0.3024 \\
EKSPOR does not Granger Cause PHLN & & 1.57563 & 0.2267 \\
\hline \hline NILAI_TUKAR does not Granger Cause EKSPOR & \multirow{2}{*}{30} & 5.04618 & 0.0144 \\
EKSPOR does not Granger Cause NILAI_TUKAR & & 1.29170 & 0.2925 \\
\hline \hline NILAI_TUKAR does not Granger Cause PHLN & \multirow{2}{*}{30} & 0.84159 & 0.4429 \\
PHLN does not Granger Cause NILAI_TUKAR & & 0.93650 & 0.4053 \\
\hline \hline
\end{tabular}

Sumber: eviews 10 Data Diolah,2020

Berdasarkan tabel 4.4 hasil uji kausalitas granger dapat dilihat bahwa variabel ekspor tidak memiliki hubungan searah terrhadap cadangn devisa yaitu sebesar $0.37<0,05$. berbeda dengan variabel cadangan devisa yang langsung memiliki hubungan terhadap ekspor, dibuktikan oleh nilai probabilitas granger lebih kecil dari tingkat kepercayaan 0,05 (5\%) yaitu sebesar 0.0011 < 0,05 .

Variabel PHLN (pembayaran hutang luar negeri) tidak memiliki hubungan terhadap terhadap cadangan devisa begitupun sebaliknya, cadangan devisa tidak memiliki hubungan terhadap pembayaran hutang luar negeri (PHLN). yang dibuktikan oleh nilai probabilitas granger lebih besar dari tingkat kepercayaan 0,05 (5\%) yaitu sebesar $0.5694>0,05$ dan $0.7336>0,05$.

Variabel nilai tukar tidak memiliki hubungan terhadap cadangan devisa begitupun sebaliknya, cadangan devisa juga tidak memiliki hubungan nilai tukar. yang dibuktikan oleh nilai probabilitas granger lebih besar dari tingkat kepercayaan 0,05 (5\%) yaitu sebesar $0.3244>0,05$ dan 0.2109>0,05.

Variabel PHLN ( pembayaran hutang luar negeri) tidak memiliki hubungan terhadap ekspor begitupun sebaliknya, ekspor tidak memiliki hubungan terhadap pembayaran hutang luar negeri (PHLN). yang dibuktikan oleh nilai probabilitas granger lebih besar dari tingkat kepercayaan 0,05 $(5 \%)$ yaitu sebesar $0.3024>0,05$ dan $0.2267>$ 0,05 .

Variabel nilai tukar memiliki hubungan terhadap ekspor. yang dibuktikan oleh nilai probabilitas granger lebih kecil dari tingkat kepercayaan 0,05 (5\%) yaitu sebesar $0.0144>0,05$ Namun ekspor tidak memiliki hubungan terhadap cadangan devisa. yang dibuktikan oleh nilai probabilitas granger lebih besar dari tingkat kepercayaan 0,05 (5\%) yaitu sebesar 0.2925>0,05.

Variabel nilai tukar tidak memiliki hubungan terhadap Pembayaran hutang luar negeri begitupun sebaliknya, Pembayaran hutang luar negeri juga tidak memiliki hubungan nilai tukar. yang dibuktikan oleh nilai probabilitas granger lebih besar dari tingkat kepercayaan $0,05(5 \%)$ yaitu sebesar $0.4429>0,05$ dan 0.4053>0,05.

Bedasarkan hasil uji kausalitas granger dapat disimpulkan bahwa keseluruhan variabel tidak memiliki hubungan antar variabel, hanya pada variabel cadangan devisa terhadap ekspor dimana nilai probabilitasnya lebih kecil dengan 0,05 atau $0.0011<0.05$.

\section{Uji Kointegrasi Bound Test}

Maksud uji kointergrasi dilakukan untuk melihat apakah terjadi hubungan jangka pendek maupun jangka panjang dan kemungkinan adanya ketidakseimbangan antara variabel independen dengan variabel dependen. Dengan 
ketidakseimbangan ini maka dibutuhkan suatu model koreksi kesalahan. Dalam penelitian ini untuk melakukan uji kointegrasi menggunakan uji bound test.

\section{Uji Bound Test}

Pada pendekatan uji Bound Test, dengan membandingkan nilai F-statistik > I0 Bound. Jika terjadi kointegrasi pada uji bound test maka penelitian ini menggunakan model Auto Regressive Distribute Lag ( ARDL ) apabila tidak terkointegrasi maka menggunakan model VAR. berikut pengujian bound test

Tabel 4.4 Uji Bound Test

\begin{tabular}{|c|c|c|c|c|}
\hline \multirow{2}{*}{$\begin{array}{l}\text { Tabel } \\
\text { F-Bounds Test } \\
\text { Test Statistic }\end{array}$} & \multirow[b]{2}{*}{ Value } & \multicolumn{3}{|c|}{$\begin{array}{l}\text { Null Hypothesis: No levels } \\
\text { relationship }\end{array}$} \\
\hline & & Signif. & $I(0)$ & I(1) \\
\hline \multirow{3}{*}{$\begin{array}{l}\text { F-statistic } \\
\text { K }\end{array}$} & \multirow{3}{*}{$\begin{array}{c}7.760713 \\
3\end{array}$} & \multicolumn{3}{|c|}{$\begin{array}{c}\text { Asymptotic } \\
\approx n=1000\end{array}$} \\
\hline & & $10 \%$ & 2.37 & $\begin{array}{r}3.2 \\
3.67\end{array}$ \\
\hline & & $\begin{array}{r}2.5 \% \\
1 \%\end{array}$ & $\begin{array}{l}3.15 \\
3.65\end{array}$ & $\begin{array}{l}4.08 \\
4.66\end{array}$ \\
\hline \multirow[t]{4}{*}{ Actual Sample Size } & \multirow[t]{4}{*}{30} & \multicolumn{3}{|c|}{$\begin{array}{c}\text { Finite } \\
\text { Sample: } \\
\text { n=30 }\end{array}$} \\
\hline & & $10 \%$ & 2.676 & 3.586 \\
\hline & & $5 \%$ & 3.272 & 4.306 \\
\hline & & $1 \%$ & 4.614 & 5.966 \\
\hline
\end{tabular}

Sumber: data diolah eviews 2020

Berdasarkan tabel 4.9.2 uji bound test hasil pengujian kointegrasi dengan menggunakan pendekatan Bound test menunjukkan terjadinya kointergrasi dimana nilai $\mathrm{F}$ statistik lebih besar dari I0 bound, dimana F Statistik > I0 bound baik pada taraf kepercayaan 10\%, 5\% Maupun $1 \%$ yaitu variabel cadangan devisa Indonesia (sebagai variabel terikat), ekspor, pembayaran hutang luar negeri dan nilai tukar. Terlihat signifikan dari kontegrasi itu hingga hampir $99 \%$.

\section{Hasil Estimasi Model ARDL}

Setelah melakukan penginputan dan pengujian stasioneritas, kointegrasi kemudian dilakukan pengolahan terhadap data dengan analisis ARDL. Pengolahan data diagi menjadi dua bagian, yaitu pengolahan jangka pendek dan pengolahan jangka panjang.

\section{Uji jangka pendek}

Pengolahan jangka pendek menghasilkan olahan hasil estimasi jangka pendek. Hasil estimasi jangka pendek menunjukkan bahwa cadangan devisa dipengaruhi secara nyata oleh ekspor, pembayaran hutang luar negeri dan nilai tukar.
Tabel 4.5 Hasil uji jangka pendek

\begin{tabular}{crrrr}
\hline \hline Variable & Coefficient & Std. Error & t-Statistic & Prob. $^{*}$ \\
\hline \hline CADEV(-1) & 0.656806 & 0.184549 & 3.558973 & 0.0021 \\
CADEV(-2) & 0.286681 & 0.207900 & 1.378935 & 0.1839 \\
EKSPOR & 0.184427 & 0.098046 & 1.881038 & 0.0754 \\
EKSPOR(-1) & -0.326961 & 0.119828 & -2.728573 & 0.0133 \\
EKSPOR(-2) & 0.289395 & 0.087936 & 3.290969 & 0.0038 \\
PHLN & 1.183901 & 0.300814 & 3.935652 & 0.0009 \\
PHLN(-1) & -0.713469 & 0.216846 & -3.290216 & 0.0038 \\
NILAI_TUKAR & -4.332982 & 0.954766 & -4.538266 & 0.0002 \\
NILAI_TUKAR(-1) & 1.525886 & 1.455579 & 1.048302 & 0.3077 \\
NILAI_TUKAR(-2) & 1.327883 & 1.096558 & 1.210955 & 0.2408 \\
C & -110.2781 & 2845.633 & -0.038753 & 0.9695 \\
\hline \hline
\end{tabular}

Sumber: eviews10 Data Diolah ,2020

Berdasarkan tabel 4.5 hasil uji jangka pendek dapat diformulasikan sebagai berikut :

\section{Cadangan Devisa $=-110.2781+0.184427$ Ekspor +1.183901 pembayaran hutang luar negeri (PHLN) - -4.332982 Nilai tukar}

Berdasarkan formulasi tersebut terlihat nilai costanta sebesar -110.2781 artinya apabila ekspor, pembayaran hutang luar negeri dan nilai tukar bernilai konstan dalam jangka panjang maka cadangan devisa menurun sebesar USD 1.102.781 juta per tahun. Kemudian pada variabel ekspor sebesar 0.184427 artinya apabila ekspor meningkat sebesar 1 juta maka cadangan devisa akan meningkat sebesar USD 0.184 .427 juta per tahun. Ekspor berpengaruh positif dan tidak signifikan karena nilai probbabilitas nya $0.0754>0.05$. kemudian pada variabel pembayaran hutang luar negeri PHLN adalah sebesar 1.183901 Artinya apabila pembayaran hutang luar negeri meningkat sebesar 1 miliar maka cadangan devisa akan meningkat sebesar USD 1.183.901 juta per tahun. Pembayaran hutang luar negeri berpengaruh positif dan signifikan karena nilai probbabilitas nya 0.0009 $<0.05$ dan kemudian pada variabel nilai tukar adalah - 4.332982 artinya apabila nilai tukar meningkat seribu rupiah maka cadangan devisa akan menurun sebesar USD 4.332.982 juta per tahun nilai tukar berpengaruh negatif dan signifikan terhadap cadangan devisa dimana terihat nilai probabilitas $0.0002<0.05$.

\section{Uji Jangka Panjang}

Adapun pengolahan jangka panjang menghasilkan olahan hasil estimasi jangka panjang. Hasil estimasi jangka panjang menunjukkan bahwa cadangan devisa dalam jangka pendek lebih dari enam bulan tidak dipengaruhi oleh ekspor. 
Pembayaran hutang luar negeri dan nilai tukar karena semua variabel nilai prob nya lebih besar dari tingkat kepercayaan $0.05(5 \%)$.

Tabel. 4.6 Hasil Uji Jangka Panjang

\begin{tabular}{ccccc}
\hline \hline Variable & Coefficient & Std. Error & t-Statistic & Prob. \\
\hline \hline EKSPOR & 2.598723 & 5.789352 & 0.448880 & 0.6586 \\
PHLN & 8.324324 & 27.42726 & 0.303505 & 0.7648 \\
NILAI_TUKAR & -26.17475 & 85.10345 & -0.307564 & 0.7618 \\
C & -1951.378 & 47763.48 & -0.040855 & 0.9678 \\
\hline \hline
\end{tabular}

Sumber: eviews10 Data Diolah,2020

Berdasarkan Tabel. 4.6 hasil uji jangka panjang hasilnya dengan menggunakan model ARDL pada tabel tersebut maka dapat diformulasikan sebagai berikut:

\section{Cadangan Devisa $=-1951.378-2.5987$ Ekspor +8.3243 pembayaran hutang luar negeri (PHLN) - 26.1747 Nilai tukar}

Adapun intepretasi persamaannya adalah pada Constanta sebesar -1951.378 artinya apabila ekspor, pembayaran hutang luar negeri dan nilai tukar bernilai konstan dalam jangka panjang maka cadangan devisa menurun sebesar USD. 1.951.378 juta per tahun. Kemudian pada variabel ekspor sebesar 2.598723 artinya apabila ekspor meningkat sebesar 1 juta maka cadangan devisa akan meningkat sebesar USD. 2.598723 juta per tahun. Variabel ekspor berpengaruh positif tetapi tidak signifikan terhadap cadangan devisa dimana terihat nilai probabilitas $0.6586>$ 0.05. kemudian pada variabel pembayaran hutang luar negeri sebesar 8.324324 artinya apabila pembayaran hutang luar negeri meningkat sebesar 1 miliar maka cadangan devisa akan meningkat sebesar USD 8.324.324 juta per tahun. Variabel pembayaran hutang luar negeri berpengaruh positif tetapi tidak signifikan terhadap cadangan devisa dimana terihat nilai probabilitas $0.7648>0.05$. Dan pada variabel Nilai tukar sebesar - 26.17475 artinya apabila nilai tukar meningkat seribu maka cadangan devisa akan menurun sebesar USD 2.617.475 per tahun. Variabel nilai tukar berpengaruh negatif tetapi tidak signifikan terhadap cadangan devisa dimana terihat nilai probabilitas $0.7618>0.05$.

\section{Pengujian Stabilitas Model ARDL}

Dalam pengujian stabilitas structural model dapat dibedakan atas dua, CUSUM (Cumulative
Sum of Recursive Residual) dan CUSUMQ (Cumulative Sum of Square of Recursive Residual). Berikut ini yaitu hasil pengujian CUSUM dengan variabel cadangan devisa sebagai variabel dependent.

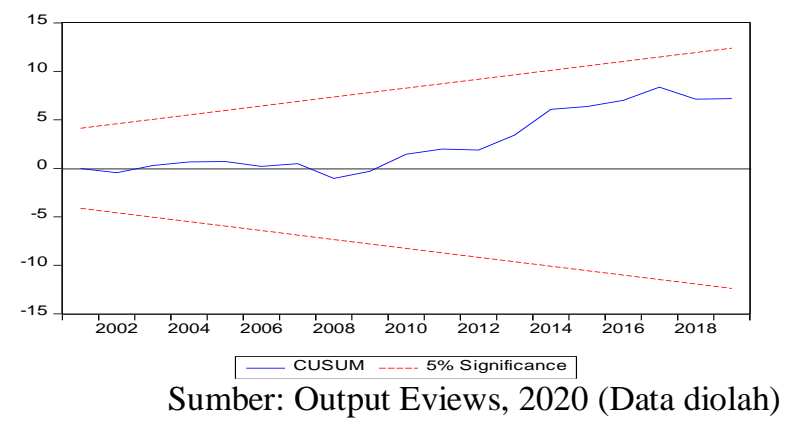

\section{Gambar 4.5 Hasil Pengujian CUSUM Test}

Berdasarkan Gambar 4.5 hasil pengujian CUSUM Test dapat di jelaskan yaitu plot kuantitas Wr tidak berada di atas garis batas pada tingkat signifikan 5\%, plot tersebut membentuk suatu garis linear. Dapat disimpulkan jika koefisien hasil regresi tersebut bersifat stabil.

\section{Pembahasan \\ Pembahasan Jangka Pendek Antar Variabel}

Berdasarkan hasil pengujian yang telah dianalisis dapat disimpulkan bahwa ekspor dalam jangka pendek berpengaruh positif terhadap cadangan devisa. Artinya setiap peningkatan ekspor dalam jangka pendek maka akan menyebabkan peningkatan cadangan devisa Indonesia. Hasil penelitian ini didapatkan dalam jangka pendek yaitu apabila ekspor meningkat sebesar 1 juta USD maka cadangan devisa Indonesia juga akan meningkat sebesar USD 0.289.395 juta hal ini sejalan dengan penelitian Benny 2011 berjudul ekspor dan impor pengaruhnya terhadap posisi cadangan devisa di Indonesia tahun 1985-2011 menggunakan model analisis linear berganda hasilnya ekspor berpengaruh positif dan signifikan terhadap cadangan devisa. Hal ini ditunjukkan oleh koefisien regresi Ekspor yaitu sebesar $(+2.131461)$. Artinya setiap kenaikan Ekspor sebesar 1 juta USD maka cadangan devisa akan naik sebesar 2.131.461 juta USD, ceteris paribus. hal ini telah sesuai dengan teori yang menyatakan bahwa jika ekspor meningkat maka jumlah cadangan devisa yang dimiliki akan ikut meningkat sehingga persediaan impor dalam beberapa bulan berikutnya akan tercukupi dan akan memperbesar kemampuan negara tersebut melakukan transaksi ekonomi.

Pada variabel pembayaran hutang luar negeri, hasil analisis dalam jangka pendek variabel pembayaran hutang luar negeri tersebut berpengaruh positif dan signifikan terhadap 
cadangan devisa Indonesia. Artinya setiap peningkatan pembayaran hutang luar negeri dalam jangka pendek maka akan menyebabkan cadangan devisa Indonesia meningkat. Hal ini berbanding terbalik dengan teorinya jika pembayaran dilakukan terus menerus dalam jangka pendek akan menguras cadangan devisa penelitian ini sejalan dengan penelitian Sihombing 2018 berjudul pengaruh ekspor, impor, dan pembayaran utang luar negeri pemerintah terhadap cadangan devisa negara Indonesia tahun 1980 - 2016 menggunakan model analisis VECM hasilnya dimana variabel pembayaran utang luar negeri pemerintah mempunyai pengaruh negatif dan signifikan terhadap cadangan devisa yaitu sebesar 2.466270 persen. Artinya, jika terjadi kenaikan pembayaran utang luar negeri pemerintah maka akan menyebabkan penurunan cadangan devisa sebesar 2.466.270 persen. Akan tetapi hasil penelitian ini sejalan dengan realita yang terjadi dimana pemerintah Indonesia hanya membayar sebagian kecil dari total hutang luar negerinya.

Pada variabel nilai tukar dalam jangka pendek berpengaruh negatif dan signifikan terhadap cadangan devisa dimana terihat nilai probabilitas $0.0002<0.05$. artinya peningkatan di sini bermaksud bahwa jumlah rupiah yang dipertukarkan dengan setiap 1 USD semakin meningkat. Dengan kata lain nilai rupiah semakin terdepresiasi ataupun terjadi pelemahan nilai tukar, maka akan menyebabkan penurunan cadangan devisa. Cadangan berperan untuk menstabilkan nilai tukar. Hasil penelitian ini sejalan dengan penelitian Sonia dkk 2016 berjudul pengaruh kurs, jub dan tingkat inflasi terhadap ekspor, impor dan cadangan devisa indonesia hasilnya menunjukkan pengaruh langsung kurs negatif dan signifikan terhadap cadangan devisa. nilai probabilitas sebesar 0.037 $<0.05$ ini berarti H0 ditolak H1 diterima, artinya kurs (X1) berpengaruh negatif dan signifikan terhadap cadangan devisa (Y3).

\section{Pembahasan dalam jangka Panjang antar variabel}

Berdasarkan hasil analisis jangka panjang pada variabel ekspor. Ekspor berpengaruh positif terhadap cadangan devisa Apabila ekspor meningkat sebesar 1 juta maka cadangan devisa akan meningkat sebesar USD. 2.598723 juta per tahun. Akan tetapi pengaruhnya tidak signifikan terhadap cadangan devisa indonesia karena nilai probabilitas nya $0.6586>0.05$. selama ini ekspor tidak memberikan kontribusi yang signifikan terhadap peningkatan cadangan devisa akan tetapi sektor Penambahan hutang luar negeri dan investasi langsunglah yang banyak memberikan kontribusi terhadap peningkatan cadnagan devisa. hal ini sejalan dengan penelitian yang dilakukan oleh Sayoga 2017 berjudul analisis cadangan devisa Indonesia dan faktor-faktor yang mempengaruhinya tahun 2000 - 2015 hasilnya Nilai ekspor mempengaruhi cadangan devisa secara signifikan. Dimana nilai ekspor mempunyai hubungan positif terhadap cadangan devisa selama periode 20002015. Tidak signifikannya pengaruh dari pada ekspor terhadap cadangan devisa karena selama ini perkembangan ekspor masih berpaut jauh dengan jumlah Impor Indonesia. Hal itu terlihat hampir semua produk yang tersebar di dalam negeri merupakan produk impor dari luar negeri. Oleh karena itu pemerintah perlu memberikan fokus yang lebih optimal terhadap sektor ekspor Indonesia sehingga kedepan sektor ekspor dapat berpengaruh positif dan signifikan terhadap cadangan devisa indonesia

Pada variabel pembayaran hutang luar negeri. Dalam jangka panjang pembayaran hutang luar negeri berpengaruh positif terhadap cadangan devisa Indonesia. Dimana jika pembayaran hutang luar negeri meningkat maka cadangan devisa juga akan meningkat. Variabel pembayaran hutang luar negeri berpengaruh positif akan tetapi tidak signifikan karena nilai probabilitsnya $0.7648>0.05$

Sepatutnya secara tanda hasil output coefisien regresnya harus negatif karena semakin bertambahnya jumlah pembayaran hutang luar negeri maka cadangan devisa Indonesia akan berkurang, akan tetapi dari hasil penelitian ini kenyataannya sangat kontras terjadi dimana tandanya adalah positif dan nilai nya juga besar tentu menjadi dilema dalam pemikiran dimana sebagai alasan yang dapat kita paparkan adalah sedikitnya pelunasan hutang yang di lakukan oleh pemerintah bahkan hanya bunganya saja itu pun jumlahnya hanya $1 \%$ jika di bandingkan dengan jumlah penambahan hutang luar negeri pemerintah pada tahun 2018 yang menembus 4000 triliun (Genjar, 2018) oleh karena itu menjadi logis hasil penelitian ini dari nilai positif dari coefisien regresi pembayaran hutang luar negeri.

Sedangkan pada variabel nilai tukar. Dalam jangka panjang nilai tukar berpengaruh negatif dimana nilai coeffisiennya sebesar - 26.1747. Maka apabila nilai tukar meningkat Rp. 1.000 maka cadangan devisa akan menurun sebesar USD 26.17475 juta per tahun. Karena selama ini cadangan devisa berperan penting dalam mengobati nilai tukar rupiah. Ketika nilai tukar melemah 
terhadap dollar USD maka cadangan devisa berperan untuk menguatkan kembali nilai tukar. Hal ini terlihat seperti pada masa krisis moneter yang membuat nilai tukar rupiah mengalami terdepresiasi berat. Nilai tukar berpengaruh negatif dan tidak signifikan terhadap cadangan devisa karena nilai probabilitasnya $0.7618>0.05$ hasil penelitian ini berbanding terbalik dengan penelitian Sayoga 2017 berjudul analisis cadangan devisa Indonesia dan faktor-faktor yang mempengaruhinya tahun $2000-2015$ menggunakan model dua analisis yaitu analisis deskriptif dan analisis kuantitatif yang menyatakan bahwa kurs rupiah terhadap US dollar mempengaruhi cadangan devisa secara signifikan. Dimana kurs berpengaruh negatif terhadap cadangan devisa selama periode 20002015.

Tidak signifikannya karena stok cadangan devisa yang di miliki oleh Indonesia masih sangat terbatas jika di bandingkan dengan negara maju sehingga cadangan devisa Indonesia belum mampu menguatkan nilai tukar, dalam jangka panjang berdasarkan data BPS hal itu terlihat bagaimana pelemahan nilai tukar rupiah pada sebelum krisis moneter ditahun 1988 yaitu Rp 1,729 selisihnya sangat jauh dan cenderung mengikuti arus meningkat tiap tahunnya hingga di tahun 2019 yaitu Rp 13,901. Cadangan devisa Indonesia belum mampu berperan untuk menguatkan kembali nilai tukar rupiah terhadap dollar AS. Dan begitupun sebaliknya nilai tukar yang tidak adanya penguatan dalam jangkan panjang tidak mempengaruhi secara signifikan terhadap cadangan devisa Indonesia.

\section{PENUTUP}

\section{Kesimpulan}

Berdasarkan hasil analisis yang telah diuraikan di atas maka dapat ditarik beberapa kesimpulan yaitu :

1. Pada variabel ekspor dalam jangka pendek ekspor berpengaruh positif sebesar 0.184427 dan tidak signifikan terhadap cadangan devisa indonesia dimana nilai probbabilitasnya sebesar $0.0754<0.05$. sedangkan dalam jangka panjang Variabel ekspor berpengaruh positif juga tidak signifikan terhadap cadangan devisa dimana terihat nilai probabilitas $0.6586>$ 0.05. pada variabel ekspor tidak ada hubungan kausalitas granger terhadap cadangan devisa. Akan tetapi hanya cadangan devisa terhadap ekspor yang memiliki hubungan kausalitas atau searah.
2. Pada variabel pembayaran hutang luar negeri dalam jangka pendek Pembayaran hutang luar negeri berpengaruh positif yaitu 1.183901dan signifikan karena nilai probbabilitasnya $0.0009<0.05$ sedangkan dalam jangka panjang variabel pembayaran hutang luar negeri berpengaruh positif sebesar 8.324324 tetapi tidak signifikan terhadap cadangan devisa dimana terihat nilai probabilitas $0.7648>0.05$. variabel pembayaran hutang luar negeri tidak memiliki hubungan kausalitas granger terhadap cadangan devisa. Begitu juga cadangan devisa terhadap pembayaran hutang luar negeri juga tidak memiliki hubungan kausalitas.

3. Pada variabel nilai tukar dalam jangka pendek nilai tukar berpengaruh negatif sebesar 4.332982 dan signifikan terhadap cadangan devisa krena nilai probabilitas $0.0002<0.05$. Namun dalam jangka panjang Variabel nilai tukar berpengaruh negatif sebesar - 26.17475 tetapi tidak signifikan terhadap cadangan devisa dimana terihat nilai probabilitas $0.7618>0.05$. variabel nilai tukar tidak memiliki hubungan kausalitas granger terhadap cadangan devisa. Begitu juga cadangan devisa terhadap nilai tukar juga tidak memiliki hubungan kausalitas.

\section{Saran}

Hasil penelitian yang telah dilakukan, maka saran yang diberikan :

1) Perlu adanya peningkatan dan Pengembangan terhadap sumber cadangan devisa Indonesia yang tidak hanya mengandalkan sektor utama sebagai pendapatan perdagangan. Pemanfaatan teknologi secara maksimal dan pemanfaatan sektor ekonomi lainnya perlu dilakukan untuk peningkatan sektor investasi sehingga dapat meningkatkan sektor ekspor yang lebih baik.

2) Bagi pemerintah membuat kebijakan yang mendukung peningkatan cadangan devisa Indonesia. Karena cadangan devisa berperan penting dalam ketahanan sektor eksternal.

3) Bagi Badan Pusat Statistik (BPS) perlu kiranya mengupdate data tepat pada waktu. Dan menyelaraskan kesamaan data dengan instansi-instansi terkait dalam pelaporan data. Sehingga dapat memudahkan peneliti selanjutnya. 


\section{KEPUSTAKAAN}

Asrianti, delima, sihombing. (2018). PENGARUH EKSPOR, IMPOR, DAN PEMBAYARAN UTANG LUAR NEGERI PEMERINTAH TERHADAP CADANGAN DEVISA NEGARA INDONESIA TAHUN $1980-2016$. https://doi.org/10.1017/CBO9781107415324 .004

Benny, J. (2011). EKSPOR DAN IMPOR PENGARUHNYA TERHADAP POSISI CADANGAN DEVISA DI INDONESIA. 1(4), 1406-1415.

Benny, J. (2013). Ekspor Dan Impor Pengaruhnya Terhadap Posisi Cadangan Devisa Di Indonesia. Jurnal Riset Ekonomi, Manajemen, Bisnis Dan Akuntansi, 1(4), 1406-1415.

Devi Andriyani, I. (2019). Kointegrasi Inflasi, Ekspor Minyak Kelapa Sawit Dan Pertumbuhan Ekonomi Di Indonesia. Jurnal Ekonomika Indonesia, VIII(01), 8-18.

Fadhilah Nu, S. R. (2017). PENGARUH SERTIFIKAT BANK INDONESIA SYARIAH (SBIS), JAKARTA ISLAMIC INDEX (JII), TINGKAT INFLASI, DAN INDEX HARGA SAHAM GABUNGAN (IHSG) TERHADAP NILAI TUKAR : PENDEKATAN AUTOREGRESSIVE DISTRIBUTED LAG (ARDL). Jurnal Ekonomi Syariah Teori Dan Terapan, 4, 833-846.

Genjar, K., Oktavia, I., \& Chandra, Y. A. (2018). Pro Kontra Hutang Dan Pembangunan Infrastruktur Indonesia. 1, 423-433.

Iskandar Putong. (2013). ECONOMICS Pengantar Mikro Dan Makro (M. . cecep hidayat,.Drs., D. Soekarno, \& M. . Tri Mulyani Setyowati, SE (eds.); 5th ed.).

Kuswantoro, M. (2017). Tirtayasa EKONOMIKA Vol. 12, No 1, April 2017. 12(1), 146-168.

Marulitua, sahat, Togatorop, djinar Nyoman, S. (2017). PENGARUH UTANG LUAR NEGERI, NET EKSPOR, dan BELANJA WISATAWAN MANCANEGARA TERHADAP CADANGAN DEVISA DI NEGARA INDONESIA TAHUN 19942013. E-JURNAL EKONOMI PEMBANGUNAN UNVERSITAS UDAYANA, 6(6), 2-29.

Marwanti, S., \& Irianto, Heru, S. (2017). PERTUMBUHAN SEKTOR PERTANIAN INDONESIA The Effects of Export, Import , and Investment on the Growth of the
Indonesian Agricultural Sector. Jurnal Agro Ekonomi, 35(1), 49-65.

Masta, S. (2014). Analisis Vector Autoregresion( Var ) Terhadap Interrelationship Antara Ipm Dan Pertumbuhan.

MUFIDAH AINI ROFATUL. (2011). METODE PHILLIPS-PERRON TEST UNTUK MENGUJI STASIONERITAS DATA INFLASI.

Pridayanti, A. (2014). Pengaruh Ekspor, Impor dan Nilai Tukar Terhadap Pertumbuhan Ekonomi Indonesia 2002-2012. Jurnal Pendidikan Ekonomi, 2(2).

Puspita, C. A. (2017). Analisis Vector Error Correction Model (VECM) Terhadap Data Kurs , BI Rate dan Inflasi di Indonesia Pada Bulan Juli 2005 - JULI 2016. 2016.

Ridho, M. (2015). Pengaruh Inflasi, Kurs Rupiah, Utang Luar Negeri Dan Ekspor Terhadap Cadangan Devisa Indonesia. E-Jurnal Perdagangan, Industri Dan Moneter, 3(1), 125.

Sayoga, P., \& Tan, S. (2017). Analisis cadangan devisa Indonesia dan faktor-faktor yang mempengaruhinya. 12(1), 25-30.

Zaretta, B., \& Yovita, L. (2019). HARGA SAHAM, NILAI TUKARMATA UANG DAN TINGKAT SUKU BUNGA ACUAN DALAM MODEL AUTOREGRESSIVE DISTRIBUTED LAG (ARDL). Jurnal Penelitian Ekonomi Dan Bisnis, 4(1), 9-22. 